\title{
TRAINING PEMBUATAN PAKAN TERNAK AYAM KAMPUNG DENGAN MENGGUNAKAN TEKNIK PERMENTASI UNTUK MENINGKATKAN KANDUNGAN PROTEIN DAN MENGHILANGKAN BAU PADA KOTORAN AYAM DI PONPES ALQUR'AN YATIM HIMMATUL 'ULYA KECAMATAN WARUNGGUNUNG KABUPATEN LEBAK
}

\author{
Tahta Anedea ${ }^{1}$, Wahyudin ${ }^{2}$, Surasa $^{3}$ \\ Universitas Pamulang \\ dosen02558@unpam.ac.id
}

\begin{abstract}
There has been an epidemic (Covid 19) that has almost a year, causing a growing desire for a simple and economical feed manufacture, making chicken feed from a fermentation system. The making of this feed is done by establishing of training for the students in the Al-quran Alquran Yatim Himmatul 'Ulya Islamic boarding school and the surrounding community. The method used is the training and discussion method. The training was given on how to make fermented chicken feed and its benefits. The activity is expected to increase the knowledge and insight of the students regarding the good impact, so that the students understand what must be prepared and needed to make fermented chicken feed, besides that it can foster an entrepreneurial spirit by developing and producing chickens with easy, practical chicken feed., rich in protein and environmentally friendly because with this feed, chicken manure is odorless. There are 20 participants who attended, most of the responses were positive.
\end{abstract}

Key Words: Chicken Feed, Training, And Fermentation.

\begin{abstract}
ABSTRAK
Terdapat wabah (Covid 19) yang hampir setahun, menyebabkan tumbuhnya keinginan pada pembuatan pakan yang simple dan hemat yaitu membuat pakan ayam dari sistem fermentasi. Pembuatan pakan ini dilakukan dengan cara pemberian training kepada para santri -santri yang ada di Ponpes Ponpes Alqur'an Yatim Himmatul 'Ulya maupun masyarakat daerah sekitar. Metode yang digunakan dengan metode training dan diskusi. Training yang diberikan mengenai cara- cara membuat pakan ayam fermentasi dan manfaatnya. Kegiatan diharapkan dapat meningkatkan pengetahuan dan wawasan para santri mengernai dampak yang baik ditimbulkan, sehingga para santri memahami apa saja yang harus disiapkan dan dibutuhkan untuk membuat pakan ayam fermentasi, selain itu dapat menumbuhkan jiwa wiraswasta dengan mengembangkan dan memproduksi ayam dengan pakan ayam yang mudah, praktis, kaya protein dan ramah ramah lingkungan karena dengan pakan ini, kotoran ayam tidak berbau. Dari 20 peserta yang hadir sebagian besar responnya positif.
\end{abstract}

Kata Kunci: Pakan Ayam, Training, Dan Fermentasi. 


\section{A. PENDAHULUAN}

\section{Analisis situasi}

Semenjak munculnya krisis wabah corona awal tahun 2020 banyak menimbulkan krisis salah satunya krisis ekonomi, kondisi peternakan unggas yang merupakan salah satu penyedia pangan masyarakat mengalami imbasnya. Salah satu penyebab peternakan unggas mengalami krisis adalah meningkatnya biaya pakan ternak yang mempunyai konnsumsi $70-80 \%$ dari biaya produksi. Keuntungan yang memadai merupakan tujuan peternak, sehingga perlu dicari agar biaya produksi terutama masalah pakan dapat ditekan, diantaranya menggunakan pakan secara efisien berupa pemberian ransum sesuai periode pertumbuhan ayam.

Agar pertumbuhan dan produksi maksimal maka jumlah dan kandungan zat-zat makanan yang diperlukan ternak harus memadai (supridjatna 2008). Untuk mendapatkan pakan ternak yang memadai maka dilakukan suatu tindakan mencari bahan-bahan alternatif lain yang berpotensi menjadi bahan pakan penyusun ransum ayam. Syarat pemilihan bahan pakan yang dapat digunakan sebagai ransum ayam adalah mudah didapat dan harganya terjangkau, tidak beracun dan mengandung zat makanan yang dibutuhkan oleh ternak itu sendiri (Sunarso dan Christiyanto,2009). Salah satu alternatif tersebut adalah dengan memanfaatkan limbah pabrik penggilingan beras yaitu dedak / bekatul.

Proses permentasi pada dedak / bekatul dengan menggunakan EM4 peterrnakan terbukti dapat meningkatkan kandunga protein sampai 5\% dan dapat menghilangkan bau pada kotoran ternak ayam. Berdasarkan hal tersebut diatas, timbul inisiatif untuk mengaplikasikan metode tersebut dengan melakukan training pada pesantren alqur'an yatim himmatul 'ulya kecamatan warunggunung kabupaten lebak. Pemberian training ini diharapkan dapat meningkatkan pengetahuan dan wawasan santri tentang cara beternak ayam yang efektif, efisien dan ramah lingkungan serta mampu memberikan tambahan pendapatan bagi pesanten tersebut.

\section{Permasalahan Mitra (santri dan masyarakat)}

Adapun perumusan masalah Mitra, sebagai berikut:

a. Mengapa masyarakat harus mengetahui pakan ternak ayam alternatif dengan melalui proses permentasi yang murah dan ramah lingkungan ?

b. Bagaimana cara meningkatkatkan kadar protein pada pakan ternak ayam dan menghilangkan bau serta pencemaran dari kotoran ayam?

\section{Tujuan kegiatan}

Tujuan kegiatan ini untuk santri dan masyarakat, sebagai berikut :

a. Meningkatkanpengetahuan masyarakat tentang pakan ternak ayam alternatif dengan cara proses permentasi, sehingga didapatkan pakan ayam dengan kandungan protein yang lebih tinggi dan kotoran ayam lebih ramah lingkungan.

b. Memberikan wawasan inovasi baru dan tambahan pengetahuan kepada masyarakat tentang cara mendapatkan pakan ternak ayam yang berkualitas.

\section{Target Luaran}

a. Laporan Akhir PKM

b. Jurnal PKM 


\section{B. METODE PELAKSANAAN KEGIATAN}

Metode kegiatan ini berupa sosialisasi dan training dengan praktek cara memproduksi pakan ayam dengan sistem permentasi yang dilakukan oleh Tahta Anedea,S.S.,M.H, Wahyudin,S.T.,M.T,Surasa,S.T.,M.T, beberapa mahasiswa dan para santri berikut ini:

1. Tahap Persiapan

Tahap persiapan yang dilakukan meliputi:

a. Survey awal, pada tahap ini dilakukan survei ke lokasi PONPES Alquran Himmatul Ulya di Warung gunung Lebak.Banten.

b. Pemantapan dan penentuan lokasi dan sasaran. Setelah survey maka ditentukan lokasi pelaksanaan dan sasaran peserta kegiatan.

c. Penyusunan bahan/materi pembuatan pakan Ayam permentasi.

2. Tahap Pelaksanaan Penelitian

Tahap ini akan diberikan penjelasan mengenai bagaimana cara memproduksi pakan ayam dengan sistem permentasi yang bernutrisi

3. Tahap Penyuluhan

Untuk melaksanakan kegiatan tersebut digunakan beberapa metode penyuluhan yaitu:

a. Metode Ceramah

Metode ceramah dipilih untuk memberikan penjelasan tentang pentingnya mengetahui cara untuk membuat pakan ayam yang berprotein tinggi dan mengurangi kadar amoniak sehingga ramah lingkungan.

b. Metode Tanya Jawab

Metode Tanya jawab sangat penting bagi para peserta pelatihan.Metode ini memungkinkan para peserta menggali pengetahuan sebanyak-banyaknya tentang seputar peternakan Ayam yang ramah lingkungan dan efektif juga efisien.

c. Metode praktek

Metode praktek ini diberikan kepada para peserta (para santri) penyuluhan dengan memberikan contoh inovasi fermentasi ini sebagai upaya peningkatan pengembangan kemampuan pembuatan pakan Ayam tersebut.

\section{HASIL DAN PEMBAHASAN}

Rangkaian kegiatan Pengabdian Kepada Masyarakat diikuti oleh Para santri dan masyarakat sekitar yang diketuai oleh H. Choirul Amin. S. Th.I. Kegiatan ini dilakukan dengan tiga metode yaitu. Metode Persiapan, Pelaksanaan kegiatan dan Penyuluhan. Hasil dari kegiatan ini adalah memberikan motivasi, tips-tips,dan cara-cara mengenai pembuatan pakan ayam dengan bahan dedak dengan cara fermentasi.

Pakan ternak adalah campuran dua bahan baku pakan atau lebih yang disusun untuk memenuhi kebutuhan ternak selama 24 jam. Dalam pakan ternak harus mengandung bahanbahan yang dapat dicerna dan diserap dan bermanfaat bagi tubuh unggas. Bahan-bahan pakan tersebut berfungsi menyediakan energi untuk keberlangsungnya berbagai proses yang terjadi dalam tubuh unggas, menyediakan bahan-bahan untuk membangun dan memeperbaharui jaringan serta mengatur kelangsungan proses-proses di dalamnya (Sunarso dan Christianto, 2009).

Pembuat fermentasi pakan untuk ayam adalah untuk mengurangi biaya pakan, akan tetapi tidak mengurangi jumlah kandungan protein yang dibutuhkan ternak ayam, sehingga pertubuhan ayam tetap baik dan mengurangi pencemaran lingkungan yang disebabkan oleh 
kotoran ayam, karena kotoran yang dihasilkan dari pakan hasil fermentasi tidak berbau karena makanan sudah diurai oleh bakteri selama pencernaan.

Adapun cara-cara dan apa saja bahan yang dibutuhkan dalam pembuatan pakan ternak sebagai berikut;

1. Persiapkan tempat untuk membuat fermentasi pakan

2. Jika tempat sudah siap, kemudian kita masukan bekatul atau dedak ketempat tersebut.

3. Setelah itu masukkan dalam suatu tempat air dan gula sesua takaran yang telah ditentukan serta aduk sampai rata/homogen.

4. Selanjutnya larutkan EM4 dalam larutan air gula minimal 20 menit.

5. Aduklah semua bahan campuran tadi dengan merata dan tutup rapat sampai tempat kedap udara.

6. Dibutuhkan waktu minimal 3 hari untuk menunggu proses fermentasi benar-benar jadi.

7. Jika sudah 3 hari pakan fermentasi sudah siap untuk digunakan.

Langkah pemberian pakan fermentasi ini diberikan sama seperti pemberian pakan yang diberikan pakan biasanya, berikan pakan fermentasi ini secara rutin, yaitu tiga kali sehari yaitu: pagi, siang dan sore hari. Penggunaan pakan fermentsi ini menyebabkan kotoran yang dihasilkan ayam tidak akan berbau tidak sedap karena kotoran sudah diurai oleh bakteri, sehingga lingkungan tidak tercemar/ tetap bersih.

\section{KESIMPULAN DAN SARAN}

Berdasarkan hasil dan pembahasan dapat disimpulkan sebagai berikut:

1. diperlukan setiap santriawan dan satriwati mengetahui pembuatan pakan ayam fermentasi dengan cara yang benar.

2. Cara meningkatkan pengembangan industri pangan yang ramah lingkuangan dapat dilakukan dengan berinovasi pembuatan pakan ayam fermentasi untuk meningkatkan kwalitas pakan ayam.

Saran yang kami berikan berdasarkan hasil kesimpulan yang didapatkan dalam Pengabdian Kepada Masyarakat yaitu diharapkan kedepannya dapat meningkatkan ketertarikan santriawan dan santriwati serta masyarakat untuk memahami pembuatan pakan ayam dengan fermentasi dan berwirausaha yakni diperlukan sosialisasi dan praktik secara berkesinambungan serta berkelanjutan. Diperlukan pula pendampingan secara riil dan perawatan menjadi langkah awal untuk dapat meningkatkan pengembangan kwalitas pakan dan produksi.

\section{DAFTAR PUSTAKA}

Anggorodi, R (1994). “Ilmu Makanan Ternak Unggas”. Kemajuan Mutakhir Universitas Indonesia Press. Jakarta.

Ilham, N. (2015). "Kebijakan Pemerintah Terhadap Usaha Unggas Skala Kecil dan kesehatan Lingkungan di Indonesia”. Wartazoa Vol. 25 No. 2 Th. 2015 Hlm 95 105.

Indarsih, B., Asnawi, D.K. Purnamasari. (2016). "Sapusapu Fish (Hyposarcus pardalis) As a Single Protein Source For Laying Mojosari Ducks”. J. Indonesian Trop. Anim. Agric: 41(3):117-24,

Mangisah, Istnah dan Bambang Sukamto. (2017). "Pelatihan Budidaya Itik Secara Semi Intensif Dan Penetasan Telur Di Desa Kebakalan Banjarnegara”. Jurnal Info. Semarang: Fakultas Peternakan dan Pertanian Universitas Diponegoro 
Sunarso dan Christiyanto. (2009). "Manajemen Pakan". Departemen Ilmu Makanan Ternak. Fakultas Peternakan. Institut Pertanian Bogor. Bogor.

Suprijatna,E, U. Atmomarsono, dan R Kartasudjana. (2008). "Ilmu Dasar Ternak Unggas". Penebar Swadaya. Jakarta.

file://D:/DOSEN\%20(Bahan\%20English\%20untuk\%20mahasiswa)/PKM/Novem\%202020/3 05-Article\%20Text-1565-1-10-20200430.pdf 